\title{
PUBLIC ADMINISTRATION IN THE FIELD OF PROVISION OF ADMINISTRATIVE SERVICES TO FOREIGNERS AND STATELESS PERSONS
}

Kornuta L. M.

\section{INTRODUCTION}

Ukraine's integration processes into the world community and the European integration course envisage the introduction of legislative and procedural changes in the system of public administration, which will ensure the unification of national legislation with international legislation. The sphere of providing administrative services to citizens is not an exception. In recent years, the theory of administrative services in Ukraine has undergone significant reform and development. At the same time, the main areas of activity on the issue of «public services» in foreign countries are the following: 1) creating the most convenient and affordable conditions for receiving services by the subjects of application; 2) search for the optimal subject of service provision, which is expressed in the creation of «executive agencies», «privatization», the use of private sector methods in public institutions, etc.; 3) introduction of information technologies for the provision of services; 4) ensuring the rights, freedoms and legitimate interests of the subjects of application, regardless of their citizenship, social status, nationality or religious beliefs. Paying attention to the identified priorities for the development and improvement of public administration of administrative services it should pay noticed the provision of administrative services to foreigners and stateless persons, because despite some universality, the order and types of administrative services for foreigners have features of normative regulation and practical implementation. In foreign countries, whence the idea of services came to us, the category of «services» in relation to the public sector is used in the broadest and most flexible sense. In fact, we are talking about «public services», «services of administration», «services for citizens» and so on. The emphasis is not on the legal component, but on the fact that all decisions or actions of the public administration in relations with the private individuals are services ${ }^{1}$. Instead,

\footnotetext{
${ }^{1}$ Публічне управління та адміністрування в умовах інформаційного суспільства: вітчизняний і зарубіжний досвід: монографія / за заг. ред. С. Чернова, В. Воронкової, В. Банаха, О. Сосніна, П. Жукаускаса, Й. Ввайнхардт, Р. Андрюкайтене; Запоріз. держ. інж. акад. Запоріжжя: ЗДІА, 2016. 606 с.
} 
Ukraine's desire for clear terminology and regulation has led to the fact that in the development of the doctrine of administrative services, despite the general unification, which is expressed in the adoption of the Law of Ukraine «On Administrative Services», there are a number of features of public services which are regulated by certain laws and bylaw acts. In particular, there are features of public administration of provision of administrative services to foreigners and stateless persons in Ukraine.

\section{Peculiarities of the procedure for stay of foreigners and stateless persons in Ukraine as subjects of application in the field of the provision of administrative services}

Defining public administration in the field of provision of administrative services to foreigners, first of all it should be noted that foreigners and stateless persons staying in Ukraine legally enjoy the same rights and freedoms, as well as have the same responsibilities as citizens of Ukraine, with the exceptions established by the Constitution, laws or international treaties of Ukraine. Foreigners who are under the jurisdiction of Ukraine, regardless of the legality of their stay, have the right to recognition of their legal personality and fundamental human rights and freedoms. At the same time, foreigners are obliged to strictly abide by the Constitution and laws of Ukraine, other normative legal acts, not to encroach on the rights and freedoms, honour and dignity of other people, the interests of society and the state $^{2}$. The main acts that determine the legal status of foreigners in Ukraine, regulate the peculiarities of their stay and determine the peculiarities of public administration in the field of receiving administrative services are the Law of Ukraine «On Legal Status of Foreigners and Stateless Persons» ${ }^{3}$ and the Law of Ukraine «On Immigration» ${ }^{4}$.

According to the Law of Ukraine «On Immigration», foreigners and stateless persons may immigrate to Ukraine for permanent residence. Foreigners and stateless persons who are recognized as refugees in Ukraine or who have been granted asylum in Ukraine are considered to be permanent residents of Ukraine from the moment of recognition as a

${ }^{2}$ Конституція України: прийнята на п'ятій сесії Верховної Ради України 28 червня 1996 р. № 254к/96-BP. URL: http://zakon.rada.gov.ua/laws/show/254\%D0\%BA/96$\% \mathrm{D} 0 \% \mathrm{~B} 2 \% \mathrm{D} 1 \% 80$ (дата звернення: 02.06.2020 р.).

${ }^{3}$ Про правовий статус іноземців та осіб без громадянства: Закон України від 22 вересня 2011 p. № 3773-VI / Верховна Рада України. URL: https://zakon.rada.gov.ua/laws/show/377317 (дата звернення: 02.06.2020 р.).

${ }^{4}$ Про імміграцію: Закон України від 07 червня 2001 р. № 2491-III / Верховна Рада України. URL: https://zakon.rada.gov.ua/laws/show/2491-14 (дата звернення: 02.06.2020р.). 
refugee in Ukraine or granting asylum in Ukraine. Foreigners and stateless persons who are recognized as persons in need of additional protection or who have been granted temporary protection in Ukraine are considered to be those who legally reside temporarily on the territory of Ukraine for the period of circumstances in which additional or temporary protection was granted. Temporary residence on the territory of Ukraine of such foreigners and stateless persons is confirmed by a certificate of a person in need of additional protection in Ukraine or a certificate of a person who has been granted temporary protection in Ukraine. At the same time, foreigners and stateless persons who, according to the law, arrived in Ukraine for employment and received a temporary residence permit are considered to be legally on the territory of Ukraine for the period of work in Ukraine. Foreigners and stateless persons who arrived in Ukraine to participate in the implementation of international technical assistance projects, duly registered, and received a temporary residence permit, are considered to be legally on the territory of Ukraine for the period of work in Ukraine. Foreigners and stateless persons who came to Ukraine to preach religious beliefs, perform religious rites or other canonical activities at the invitation of religious organizations and in agreement with the state body that registered the relevant religious organization, and received a temporary residence permit, are considered as such, who stay legally on the territory of Ukraine for the period of activity of Ukraine. Foreigners and stateless persons who entered Ukraine on other legal grounds are considered to be temporarily staying on the territory of Ukraine on legal grounds for the period of entry visa or for a period established by the legislation or international treaty of Ukraine. In addition, foreigners and stateless persons who permanently resided in Ukraine before the decision to terminate Ukrainian citizenship and remained permanent residents in Ukraine after the decision to terminate Ukrainian citizenship are considered permanent residents in Ukraine. It should be noted that all these groups of persons have the right to apply for administrative services.

According to the legislation, foreigners and stateless persons enter Ukraine with the presence of a passport and a visa obtained in the prescribed manner, unless otherwise provided by law or international treaties of Ukraine. This rule does not apply to foreigners and stateless persons crossing the state border of Ukraine for the purpose of recognizing them as refugees or persons in need of additional or temporary protection or granting asylum. Foreigners and stateless persons are required to submit their biometric data for identification during border control at border crossing points. The period 
of stay of foreigners and stateless persons in Ukraine is established by a visa, legislation of Ukraine or an international agreement of Ukraine ${ }^{5}$.

It should be noted that the procedure for obtaining a visa can be considered as a separate type of administrative service. In turn, the rules for issuing visas to foreigners and stateless persons and the list of documents required for its receipt are established by the Cabinet of Ministers of Ukraine. The decision on a visa is made in the prescribed manner by a diplomatic mission or consular post of Ukraine, the Ministry of Foreign Affairs of Ukraine or a representative office of the Ministry of Foreign Affairs of Ukraine in Ukraine. A foreigner or a stateless person may be denied obtaining a visa in the following cases: threat to the national security of the state or protection of public order, health care, protection of the rights and legitimate interests of citizens of Ukraine and other persons residing in Ukraine; stay in the database of persons who, according to the legislation of Ukraine, are not allowed to enter Ukraine or their right to leave Ukraine is temporarily restricted; submission of an invalid passport document or a passport document belonging to another person; submission of knowingly false information or forged other documents; the absence of a valid health insurance policy, provided that it is possible to issue it in the territory of the state in which the relevant visa application is submitted; lack of sufficient financial security for the period of the planned stay and for return to the country of origin or transit to a third country or the possibility to obtain sufficient financial security in a lawful manner on the territory of Ukraine; lack of evidence confirming the purpose of the planned stay; lack of documents that allow to establish the applicant's intention to leave the territory of Ukraine before the expiration of the visa; the applicant's request to terminate the consideration of the visa application. The decision to refuse a visa is made by the authorized bodies that have decided to grant and issue it.

At the same time, it should be noted that the visa may be cancelled during the border control on the grounds and in the manner prescribed by the Law of Ukraine «On Border Control» ${ }^{6}$. The visa may also be revoked during the stay of a foreigner or a stateless person on the territory of Ukraine in the case of: detection of the fact of submission by a person during the visa of an invalid or issued to another person passport document or other

\footnotetext{
${ }^{5}$ Про правовий статус іноземців та осіб без громадянства: Закон України від 22 вересня 2011 p. № 3773-VI / Верховна Рада України. URL: https://zakon.rada.gov.ua/laws/show/3773-17 (дата звернення: 02.06.2020 р.).

${ }^{6}$ Про прикордонний контроль: Закон України від 05 листопада 2009 р. № 1710-VI / Верховна Рада України. URL: https://zakon.rada.gov.ua/laws/show/1710-17 (дата звернення: 02.06.2020 p.).
} 
forged documents, or submission of knowingly false information; decisionmaking on forced return or forced expulsion of a foreigner or stateless person outside the territory of Ukraine. Visa revocation may be carried out by authorized officials of the central executive body that ensures the implementation of state policy in the field of migration, or the state border protection body; in cases, as well as by authorized officials of the body that made the decision on forced return or who filed a lawsuit to the court to make a decision on forced expulsion, but only after the court adopts such a decision. The decision to cancel a visa may be appealed in the manner prescribed by law.

A foreigner or a stateless person is not allowed to enter Ukraine: 1) in the interests of ensuring the national security of Ukraine or the protection of public order; 2) if it is necessary for the protection of health, protection of the rights and legitimate interests of citizens of Ukraine and other persons residing in Ukraine; 3 ) if a person has submitted knowingly false information or forged documents when applying for entry into Ukraine; 4) if the passport document of the person or the visa is forged, spoiled or does not correspond to the established sample or belongs to other person; 5) if such a person violated the rules of crossing the state border of Ukraine, customs rules, sanitary norms or rules at the checkpoint across the state border of Ukraine or failed to comply with legal requirements of officials and functionaries of state border guards, customs and other bodies exercising control at the state border borders; 6) if during the previous stay on the territory of Ukraine a foreigner or a stateless person has not complied with the decision of a court or public authority authorized to impose administrative penalties, or has other unfulfilled property obligations to the state, individuals or legal entities, including related with previous expulsion, including after the expiration of the ban on further entry into Ukraine. The decision to ban entry into Ukraine is made by the central executive body that ensures the implementation of state policy in the field of migration, the Security Service of Ukraine or the state border guard body. Foreigners and stateless persons who are not allowed to enter Ukraine, when attempting to enter Ukraine at a checkpoint across the state border of Ukraine do not cross the state border of Ukraine and return as soon as possible to the country from which they came or to the state, which issued a passport document. In case of impossibility of immediate return of a foreigner or a stateless person, they are at the checkpoint across the state border of Ukraine until their return. Such foreigners and stateless persons shall be marked in the passport document with a ban on entry into Ukraine for the period specified in the decision. 
Paying attention to certain features of the legal status of foreigners and stateless persons, it should be noted that being legally in Ukraine, such persons have the right to the result of the exercise of power by the subject of administrative services, aimed at acquiring, changing or terminating rights or obligations of such person in accordance with the Law of Ukraine «On Administrative Services». Administrative services are provided to foreigners on a general basis and in the manner prescribed by law. At the same time, it is worth paying attention to certain types of administrative services that can be provided to foreigners and stateless persons, which have certain features regarding the procedure for their provision.

\section{Peculiarities of registration administration and extension of the term of stay of foreigners and stateless persons on the territory of Ukraine}

First of all, it should be noted that entry into Ukraine and exit from Ukraine of foreigners and stateless persons is carried out on a passport document with a visa, unless otherwise provided by law or international treaty of Ukraine. Foreigners who permanently reside on the territory of Ukraine, in addition to a passport document, must present a permanent residence permit. For stateless persons permanently residing in Ukraine, the main document is a stateless person's identity card for travel abroad. Moreover, for foreigners and stateless persons who are married to citizens of Ukraine, as well as foreigners who are in Ukraine in connection with employment, in addition to a passport, they must also obtain a temporary residence permit. Temporary residence permits are also issued to foreigners staying in Ukraine in connection with participation in the activities of religious organizations, as well as to foreigners working in representative offices of foreign economic entities, applicants for higher education in Ukraine, etc. Registration of foreigners and stateless persons entering Ukraine is carried out at checkpoints across the state border of Ukraine by state border guards. The mark on the registration of a foreigner or a stateless person in a passport document or other documents provided by the legislation of Ukraine is valid throughout the territory of Ukraine, regardless of the place of stay or residence of the foreigner or stateless person on the territory of Ukraine. This procedure for registration of foreigners and stateless persons does not apply to persons who, with the intention of recognizing them as refugees in Ukraine or a person in need of additional protection in Ukraine or obtaining asylum or temporary protection, illegally crossed the state border of Ukraine. 
The legislation defines certain cases when foreigners and stateless persons are exempted from registration. In particular, the following persons are exempted from the registration: the heads of state and government of foreign countries, members of parliamentary and governmental delegations, technical staff serving such delegations (persons) and members of their families who arrived in Ukraine at the invitation of the President of Ukraine, Verkhovna Rada of Ukraine or Cabinet Ministers of Ukraine, the Verkhovna Rada of the Autonomous Republic of Crimea or the Council of Ministers of the Autonomous Republic of Crimea, ministries and other central executive bodies of Ukraine; persons and family members of persons who arrived in Ukraine on the basis of UN certificates and organizations of the UN system; foreigners or stateless persons who have not reached the age of eighteen; foreign tourists on a cruise; crew members of foreign warships (aircraft) who arrived in Ukraine in the prescribed manner; persons who are part of the crews of foreign non-military vessels; persons who are part of the crew of civil aircraft of international airlines, crews of international trains, in the case of stay at airports or stations (depots) specified in the schedule ${ }^{7}$.

If there are legal grounds for a foreigner or a stateless person who are legally on the territory of Ukraine, the period of stay on the territory of Ukraine may be extended. Documents on extension of the term of stay in Ukraine are drawn up on the basis of written applications of a foreigner or stateless person and the host party, which should be submitted no later than three working days before the end of their stay in Ukraine. However, an extension of the stay of a foreigner or a stateless person may be refused if there are no grounds for doing so and sufficient financial security to cover the costs connected with the stay of the foreigner or stateless person in Ukraine or appropriate guarantees from the host party. Extension of the period of stay on the territory of Ukraine is carried out by the central executive body that implements the state policy in the field of migration, in accordance with the procedure established by the Cabinet of Ministers of Ukraine ${ }^{8}$. The order determines the procedure for extending the period of stay and extending or reducing the period of temporary stay of foreigners and stateless persons

\footnotetext{
7 Про правовий статус іноземців та осіб без громадянства: Закон України від 22 вересня 2011 p. № 3773-VI / Верховна Рада України. URL: https://zakon.rada.gov.ua/laws/show/3773-17 (дата звернення: 02.06.2020 р.)

${ }^{8}$ Про затвердження Порядку продовження строку перебування та продовження або скорочення строку тимчасового перебування іноземців та осіб без громадянства на території України: Постанова Кабінету Міністрів України від 15 лютого 2012 р. № 150 / Кабінет Міністрів України. URL: https://zakon.rada.gov.ua/laws/show/150-2012-\%D0\%BF (дата звернення: 02.06.2020 р.).
} 
on the territory of Ukraine. The period of stay of foreigners and stateless persons on the territory of Ukraine, passport documents or documents confirming a stateless person registered by an official of the State Border Guard Service of Ukraine is extended by territorial bodies or subdivisions of the State Migration Service.

Applications for extension of stay in Ukraine are submitted by foreigners and stateless persons and the host party not earlier than ten and not later than three working days before the end of such period to the territorial bodies or units of the State Migration Service at the place of residence. To extend the period of stay on the territory of Ukraine, a foreigner and a stateless person and the host party together with the application shall submit a list of documents attached in the Regulations ${ }^{9}$. The decision to extend the stay of foreigners and stateless persons on the territory of Ukraine beyond the statutory period is made by the head of the territorial body or unit of the State Migration Service or his deputy in case of application for immigration or citizenship of Ukraine and the existence of grounds to leave Ukraine, as well as the Head of the State Migration Service or his deputy in other cases, subject to the submission of supporting documents.

\section{Peculiarities of administration of administrative services}

\section{for obtaining a residence permit and taxpayer's account card}

Foreigners and stateless persons can obtain a permanent residence permit. The main normative acts that determine the procedure for obtaining a permanent residence permit are the Law of Ukraine «On the Legal Status of Foreigners and Stateless Persons» and the Law of Ukraine «On Immigration». According to the legislation, a permanent residence permit can be received by the foreigners and stateless persons, who immigrated to Ukraine for permanent residence, as well as persons who permanently resided in Ukraine before the decision to terminate Ukrainian citizenship and remained to live permanently on its territory after the decision to terminate Ukrainian citizenship ${ }^{10}$. At the same time in the second case, the basis for the issuance of a permanent residence permit to foreigners and stateless persons is the

\footnotetext{
9 Про затвердження Порядку продовження строку перебування та продовження або скорочення строку тимчасового перебування іноземців та осіб без громадянства на території України: Постанова Кабінету Міністрів України від 15 лютого 2012 р. № 150 / Кабінет Міністрів України. URL: https://zakon.rada.gov.ua/laws/show/150-2012-\%D0\%BF (дата звернення: 02.06.2020 р.).

${ }_{10}$ Про правовий статус іноземців та осіб без громадянства: Закон України від 22 вересня 2011 р. № 3773-VI / Верховна Рада України. URL: https://zakon.rada.gov.ua/laws/show/3773-17 (дата звернення: 02.06.2020р.).
} 
relevant decree of the President of Ukraine on termination of citizenship of Ukraine and applications of such persons.

Foreigners and stateless persons can obtain a temporary residence permit. The procedure for obtaining a temporary residence permit depends on the conditions that precede the relevant application of the person and are determined by the Law of Ukraine «On the Legal Status of Foreigners and Stateless Persons». Thus, according to Art. 5 of the Law of Ukraine «On the legal status of foreigners and stateless persons» the basis for the issuance of a temporary residence permit in the event that foreigners and stateless persons arrived in Ukraine for employment, is an application of a foreigner or stateless person, a valid health insurance policy, a permit for use of labor of foreigners and stateless persons and the employer's obligation to notify the central executive body ensuring the implementation of state policy in the field of migration and the state employment service of early termination or termination of employment contract with such foreigner or stateless person. According to the law, the grounds for issuing a temporary residence permit in the event that foreigners and stateless persons arrived in Ukraine to participate in the implementation of international technical assistance projects registered in the prescribed manner is an application of a foreigner or stateless person, a valid health insurance policy and the relevant submission of the state institution, enterprise or organization that is the recipient of the international technical assistance project. The grounds for issuing a temporary residence permit in the event that foreigners and stateless persons come to Ukraine for the purpose of preaching religious beliefs, performing religious rites or other canonical activities at the invitation of religious organizations and in agreement with the state body that registered the religious organization, is an application of a foreigner or a stateless person, a valid health insurance policy, the submission of the relevant religious organization and the approval of the state body that registered the relevant religious organization. The basis for the issuance of a temporary residence permit in the event that foreigners and stateless persons arrived in Ukraine to participate in the activities of branches, offices, representative offices and other structural units of public (non-governmental) organizations of foreign countries, duly registered, is a foreigner's or a statelessness person's application, a valid health insurance policy, the submission of the relevant branch, office, representative office or other structural unit of a public (non-governmental) organization of a foreign state in Ukraine and a copy of the certificate of registration of a structural unit of a public (non-governmental) foreign state organization in Ukraine. In turn, the basis for the issuance of a temporary residence permit 
in the event that foreigners and stateless persons arrived in Ukraine to work in representative offices of foreign business entities in Ukraine, duly registered, is an application of a foreigner or stateless person, a valid policy health insurance, submission of the relevant representative office of a foreign business entity in Ukraine and a copy of the certificate of registration of such representative office. The grounds for issuing a temporary residence permit in the event that foreigners and stateless persons have arrived in Ukraine for the purpose of study are an application of a foreigner or a stateless person, a valid health insurance policy, a document confirming the fact of study in Ukraine and institution to notify the central executive body that ensures the implementation of state policy in the field of migration about the fact of sending down from such institution. According to the law, the grounds for the issuance of a temporary residence permit in the event that foreigners and stateless persons arrived in Ukraine for the purpose of family reunification with persons who are citizens of Ukraine is an application of a foreigner or stateless person and a document confirms the fact of being married to a citizen of Ukraine, a valid health insurance policy. If a marriage between a citizen of Ukraine and a foreigner or a stateless person has been concluded outside Ukraine in accordance with the law of a foreign state, the validity of such a marriage is determined in accordance with the Law of Ukraine «On Private International Law». In the event that foreigners and stateless persons come to Ukraine for the purpose of family reunification with foreigners or stateless persons legally staying on the territory of Ukraine, it is a statement of the foreigner or stateless person, a valid health insurance policy and a document, according to which they are, in accordance with the law of the country of origin of a foreigner or a stateless person, considered members of the person's family.

A foreigner or a stateless person shall submit an application for registration or extension of a temporary residence permit and relevant documents specified by this Law and the Cabinet of Ministers of Ukraine, personally or through his representative on the basis of a power of attorney to the territorial body of the central executive body that ensures the implementation of state policy in the field of migration. The legislation establishes an exhaustive list of documents that foreigners and stateless persons submit to obtain a temporary residence permit. State authorities are prohibited from demanding from foreigners or stateless persons, members of their families, employers and other persons any other documents or information not specified in the relevant article of the Law «On the Legal Status of Foreigners and Stateless Persons». The Cabinet of Ministers of Ukraine establishes the technical 
description, samples of forms of permanent residence and temporary residence certificates, the procedure for their registration, manufacture and issuance. The temporary residence permit is issued within ten days from the date of receipt of the application for its registration or extension of the certificate. In this case, a foreigner or a stateless person submits documents for the extension of the temporary residence permit no later than 10 calendar days before the expiration of its validity ${ }^{11}$. An administrative fee is paid for the issuance or extension of a temporary residence permit.

The taxpayer's registration card is issued on the basis of an application of a foreigner or a stateless person, their representatives to the controlling body, which certifies the registration in the State Register (taxpayer's card). At the same time, the legislation defines the features for persons who, due to their religious beliefs, refuse to accept the registration number of the taxpayer's account card and have notified the relevant supervisory authority and have a mark in the passport. The procedure for applying for a taxpayer's card is determined by the Regulations on registration of individuals in the State Register of Individuals - Taxpayers ${ }^{12}$. Foreigners and stateless persons apply to the territorial bodies of the State Fiscal Service in the Autonomous Republic of Crimea, oblasts, cities of Kyiv and Sevastopol or to the State Fiscal Service, and foreigners and stateless persons who have a permanent or temporary residence permit in Ukraine, may be registered as taxpayers in the state tax inspections in districts, cities, districts in cities, joint state tax inspections, corresponding to the place of residence in Ukraine, specified in the permit. To issue a document certifying registration in the State Register, foreigners and stateless persons shall additionally submit a Ukrainian translation of a document certifying the identity of a foreigner or a stateless person and a copy of such translation (except for persons who have permanent residence permits or temporary residence permits in Ukraine).

\section{Peculiarities of administration of the order of employment of foreigners and stateless persons}

It should be noted that foreigners and stateless persons acquire the status of subjects of labor law only if they reside on the territory of Ukraine on

\footnotetext{
${ }_{11}$ Про правовий статус іноземців та осіб без громадянства: Закон України від 22 вересня 2011 p. № 3773-VI / Верховна Рада України. URL: https://zakon.rada.gov.ua/laws/show/3773-17 (дата звернення: 02.06.2020 р.)

12 Про затвердження Положення про реєстрацію фізичних осіб у Державному реєстрі фізичних осіб - платників податків: Наказ Міністерства фінансів України від 29 вересня 2009 p. № 822 / Міністерство фінансів України. URL: https://zakon.rada.gov.ua/laws/show/ z1306-17 (дата звернення: 02.06.2020 р.).
} 
legal grounds. Given the above, to start an employment relationship with a foreigner, the employer must obtain permission to use his work. Legal relations arising in the process of public administration regarding the employment of foreigners and stateless persons are regulated by the Law of Ukraine «On Employment» ${ }^{13}$, the Law «On the Legal Status of Foreigners and Stateless Persons», the Resolution of the Cabinet of Ministers of Ukraine «On approval of application forms for obtaining by the employer a work permit for foreigners and stateless persons, extension of the work permit for foreigners and stateless persons, amendments to the work permit for foreigners and stateless persons ${ }^{14}$, etc. According to the provisions of the Law of Ukraine «On Employment», along with citizens of Ukraine, only foreigners who permanently reside in Ukraine, i.e. who have received a permanent residence permit in the prescribed manner, have the right to employment. With regard to foreigners who have arrived in Ukraine for employment for a certain period, they may acquire the legal status of an employee and engage in employment only on the basis of a duly obtained employment permit. Such a permit is issued by the territorial bodies of the State Employment Service of Ukraine. The permit is issued for a particular position and for a particular period. To obtain a permit, the employer submits to the State Employment Service a standard application, a copy of the passport, a photograph of a foreigner and a copy of the draft employment contract. After receiving the permit, the employer is obliged to provide a copy to the body of the Ministry of Social Policy of Ukraine, which issued the permit, no later than 90 calendar days from the date of issuance of the permit and within 10 days after concluding the employment contract.

An employer who intends to hire a foreigner must be registered at the employment center as a payer of insurance contributions to the Fund of Compulsory State Social Insurance of Ukraine in the event of unemployment and have no debts to it, obtain a permit from the State Employment Service to use foreign labor. In order to obtain a work permit for a foreigner, the employer is obliged to submit to the State Employment Service a package of documents specified by law, which applies to both the employer and the foreigner who

\footnotetext{
13 Про зайнятість населення: Закон України від 05 липня 2012 р. № 5067-VI / Верховна Рада України. URL: https://zakon.rada.gov.ua/laws/show/5067-17 (дата звернення: 02.06.2020р.).

14 Про затвердження форм заяв для отримання роботодавцем дозволу на застосування праці іноземців та осіб без громадянства, продовження строку дії дозволу на застосування праці іноземців та осіб без громадянства, внесення змін до дозволу на застосування праці іноземців та осіб без громадянства: Постанова Кабінету Міністрів України від 15 листопада 2017 p. № 858 / Кабінет Міністрів України. URL: https://zakon.rada.gov.ua/laws/show/8582017-\%D0\%BF (дата звернення: 02.06.2020 р.).
} 
is planned to be employed. It should be noted that for the employment of foreigners who permanently reside in Ukraine and have received a permanent residence permit, the employer does not need to obtain a work permit for such persons. The full list of persons whose employment does not require a permit is determined by the Law of Ukraine «On Employment». The attention should be drawn to the fact that the legislator has also enshrined the possibility of refusing to issue a work permit to foreigners and stateless persons, but in clearly defined cases. The law also defines the grounds on which an employment permit can be revoked. In addition, it should be noticed that the issue of employment of foreigners and registration of permits is strictly controlled by the state and it is provided for the imposition of penalties on the employer if the employer employs foreigners or stateless persons in violation of the requirements prescibed by legislation.

\section{Peculiarities of administration of administrative services of medical care of foreigners and stateless persons}

Foreigners and stateless persons permanently residing or temporarily staying on the territory of Ukraine shall be provided with medical services in accordance with the norms of the Procedure for providing medical care to foreigners and stateless persons permanently residing or temporarily staying on the territory of Ukraine, who have applied for recognition as a refugee or a person in need of additional protection, in respect of whom a decision has been made to draw up documents for resolving the issue of recognition as a refugee or a person in need of subsidiary protection, and who has been recognized as a refugee or a person in need of subsidiary protection and compensation of medical services and medicines foreigners and stateless persons temporarily residing or staying on the territory of Ukraine ${ }^{15}$. It should be noted that for foreigners and stateless persons permanently residing in Ukraine, foreigners and stateless persons recognized as refugees or persons in need of additional protection, the medical care is provided at the expense of budget funds foreseen for this purpose in the state and local budgets.

\footnotetext{
${ }^{15}$ Про затвердження Порядку надання медичної допомоги іноземцям та особам без громадянства, які постійно проживають або тимчасово перебувають на території України, які звернулися із заявою про визнання біженцем або особою, яка потребує додаткового захисту, стосовно яких прийнято рішення про оформлення документів для вирішення питання щодо визнання біженцем або особою, яка потребує додаткового захисту, та яких визнано біженцями або особами, які потребують додаткового захисту, та компенсації вартості медичних послуг і лікарських засобів, наданих іноземцям та особам без громадянства, які тимчасово проживають або перебувають на території України: Постанова Кабінету Міністрів України від 19 березня 2019 р. № 121 / Кабінет Міністрів України. URL: https://zakon.rada.gov.ua/laws/ show/121-2014-\%D0\%BF (дата звернення: 02.06.2020р.).
} 
Foreigners and stateless persons temporarily residing or staying on the territory of Ukraine shall be provided with medical care on a paid basis, unless otherwise is provided by the international treaties or laws of Ukraine. The cost of medical care provided to a foreigner or a stateless person temporarily staying on the territory of Ukraine is determined by the health care institution that provided it, in accordance with the procedure established by the Ministry of Health, except for certain research institutions of the National Academy of Medical Sciences, which are participants in a pilot project to change the mechanism of financial support for medical care. In the case when the provision of medical services and medicines related to the provision of emergency medical care is paid from the state budget under the program of state guarantees of medical care (program of medical guarantees), foreigners or stateless persons temporarily residing or staying on the territory of Ukraine, are obliged to compensate the state for their full value. Compensation for the full cost of medical services and medicines provided is made by transferring the full cost of medical services and medicines provided to such medical service provider by a foreigner or a stateless person temporarily residing or staying in Ukraine. The total cost of medical services and medicines related to the provision of emergency medical care is determined at a level not lower than their cost, which is calculated by the subject of medical services and reflected in the invoice. The subject of medical services is obliged to provide an account to a foreigner or a stateless person temporarily residing or staying on the territory of Ukraine, or to their legal representatives, indicating the amount to be compensated. A foreigner or a stateless person temporarily residing or staying on the territory of Ukraine, or their legal representatives are obliged to pay such an amount of compensation on the account before leaving the territory of Ukraine. In turn, the subject of medical services is obliged to notify the Administration of the State Border Guard Service in electronic form of foreigners or stateless persons temporarily residing or staying in Ukraine, who were provided with medical services and medicines related to the provision of emergency medical care, no later than the day following the provision of such medical services, to take measures to ensure compensation to such persons for the full cost of medical services and medicines provided.

In case of concluding an insurance contract (policy, certificate, certification) by a foreigner or a stateless person temporarily staying on the territory of Ukraine with a resident insurer, which guarantees payment of the cost of medical care, the resident insurer pays the specified cost by transferring funds to the health care institution who provided medical care, 
subject to the presentation of a document for payment. In the absence of an insurance contract, the cost of medical care, including emergency, is paid by a foreigner or a stateless person.

At the same time, health care institutions have the right to provide only those types of paid services that are defined in the List of paid services that can be provided in state and municipal health care institutions, higher medical educational institutions and research institutions ${ }^{16}$. It is worth noting that at present, the Ministry of Health has issued a normative document that can only determine the cost of emergency medical care. As for other services, i.e. those that are not emergency services, no regulations have been adopted.

The issue of regulating the provision of medical services related to the spread of COVID-19 coronavirus disease in Ukraine is currently relevant. The Ministry of Health of Ukraine has clarified the provision of medical care to foreigners and stateless persons in cases related to COVID-19. For example, if a foreigner develops symptoms related to the COVID-19 infectious disease, he or she can apply to insurance companies and the health care facilities designated by them. If an infectious disease of COVID-19 is suspected, the foreigner will be referred to one of the infectious diseases hospitals for COVID-19 testing and necessary treatment ${ }^{17}$.

\section{CONCLUSIONS}

Thus, as is obvious from the foregoing, it can be argued that the Ukrainian doctrine of administrative services is an integral part of reforming and developing Ukraine as an independent, European state. Paying attention to the priority of unification of administrative services provided in Ukraine to international standards, it is extremely important to determine the procedure for public administration of administrative services provided to foreigners and stateless persons. Despite the fact that according to the general Constitutional norms, foreigners and stateless persons who are in Ukraine legally, enjoy the same rights and freedoms, as well as have the same responsibilities as citizens of Ukraine, yet the peculiarities of administration in matters of administrative services have a place to be. As a rule, normative regulation of public administration of certain administrative

\footnotetext{
${ }^{16}$ Про затвердження переліку платних послуг, які надаються в державних і комунальних закладах охорони здоров'я та вищих медичних навчальних закладах: Постанова Кабінету Міністрів України від 17 вересня 1996 р. № 1138 / Кабінет Міністрів України. URL: https://zakon.rada.gov.ua/laws/show/1138-96-\%D0\%BF (дата звернення: 02.06.2020р.).

17 Офіційний сайт Міністерства охорони здоров’я України. URL: https://moz.gov.ua/ gromadjanam (дата звернення: 02.06.2020 р.).
} 
services that can be provided to foreigners and have a special procedure of realisation is regulated by a separate normative act, and the main subject of administration is the Cabinet of Ministers of Ukraine and other executive bodies implementing state policy in the relevant field of public administration. The main features of the implementation of administrative services are as follows: 1) the allocation of certain types of administrative services that are unique to foreigners and stateless persons (administrative services to extend the period of stay in Ukraine, obtaining a permanent and temporary residence permit, etc.); 2) establishment of a separate procedure and additional procedural actions in the process of providing administrative services (employment, medical care, etc.).

\section{SUMMARY}

The article identifies the features of public administration in the field of providing certain administrative services to foreigners and stateless persons. It was found that foreigners and stateless persons staying in Ukraine legally enjoy the same rights and freedoms, as well as the same responsibilities as citizens of Ukraine. Based on the characteristics of the legal status of foreigners in Ukraine and analyzing the general legislation on administrative procedures, it is established that foreigners and stateless persons may be the subjects of applications for administrative services. At the same time, the peculiarities of the types and procedure of realization of administrative services that can be provided to foreigners and stateless persons are established. The main features of the implementation of administrative services are as follows: 1) the allocation of certain types of administrative services that are unique to foreigners and stateless persons; 2) establishment of a separate procedure and additional procedural actions in the process of providing administrative services.

\section{REFERENCES}

1. Конституція України : прийнята на п’ятій сесії Верховної Ради України 28 червня 1996 р. № 254к/96-BP. URL : http://zakon.rada.gov.ua/laws/ show $/ 254 \% \mathrm{D} 0 \% \mathrm{BA} / 96-\% \mathrm{D} 0 \% \mathrm{~B} 2 \% \mathrm{D} 1 \% 80$ (дата звернення: 02.06.2020р.).

2. Про зайнятість населення : Закон України від 05 липня 2012 p. № 5067-VI / Верховна Рада України. URL : https://zakon.rada.gov.ua/laws/ show/5067-17 (дата звернення: 02.06.2020 р.).

3. Про імміграцію : Закон України від 07 червня 2001 p. № 2491-III / Верховна Рада України. URL : https://zakon.rada.gov.ua/laws/ show/2491-14 (дата звернення: 02.06.2020 p.). 
4. Про правовий статус іноземців та осіб без громадянства : Закон України від 22 вересня 2011 р. № 3773-VI / Верховна Рада України. URL : https://zakon.rada.gov.ua/laws/show/3773-17 (дата звернення: 02.06.2020 p.).

5. Про прикордонний контроль : Закон України від 05 листопада 2009 p. № 1710-VI / Верховна Рада України. URL : https://zakon.rada.gov.ua/ laws/show/1710-17 (дата звернення: 02.06.2020 p.).

6. Про затвердження переліку платних послуг, які надаються в державних і комунальних закладах охорони здоров'я та вищих медичних навчальних закладах : Постанова Кабінету Міністрів України від 17 вересня 1996 р. № 1138 / Кабінет Міністрів України. URL : https://zakon. rada.gov.ua/laws/show/1138-96-\%D0\%BF (дата звернення: 02.06.2020р.).

7. Про затвердження Порядку надання медичної допомоги іноземцям та особам без громадянства, які постійно проживають або тимчасово перебувають на території України, які звернулися із заявою про визнання біженцем або особою, яка потребує додаткового захисту, стосовно яких прийнято рішення про оформлення документів для вирішення питання щодо визнання біженцем або особою, яка потребує додаткового захисту, та яких визнано біженцями або особами, які потребують додаткового захисту, та компенсації вартості медичних послуг і лікарських засобів, наданих іноземцям та особам без громадянства, які тимчасово проживають або перебувають на території України : Постанова Кабінету Міністрів України від 19 березня 2019 р. № 121 / Кабінет Міністрів України. URL : https://zakon. rada.gov.ua/laws/show/121-2014-\%D0\%BF (дата звернення: 02.06.2020 p.).

8. Про затвердження Порядку продовження строку перебування та продовження або скорочення строку тимчасового перебування іноземців та осіб без громадянства на території України : Постанова Кабінету Міністрів України від 15 лютого 2012 р. № 150 / Кабінет Міністрів України. URL : https://zakon.rada.gov.ua/laws/show/150-2012\%D0\%BF (дата звернення: 02.06.2020р.).

9. Про затвердження форм заяв для отримання роботодавцем дозволу на застосування праці іноземців та осіб без громадянства, продовження строку дії дозволу на застосування праці іноземців та осіб без громадянства, внесення змін до дозволу на застосування праці іноземців та осіб без громадянства : Постанова Кабінету Міністрів України від 15 листопада 2017 p. № 858 / Кабінет Міністрів України. URL : https://zakon.rada.gov.ua/ laws/show/858-2017-\%D0\%BF (дата звернення: 02.06.2020р.).

10. Про затвердження Положення про реєстрацію фізичних осіб у Державному реєстрі фізичних осіб - платників податків : Наказ Міністерства фінансів України від 29 вересня 2009 р. № 822 / Міністерство фінансів України. URL : https://zakon.rada.gov.ua/laws/show/z1306-17 (дата звернення: 02.06.2020 p.). 
11. Офіційний сайт Міністерства охорони здоров'я України. URL : https://moz.gov.ua/gromadjanam (дата звернення: : 02.06.2020 p.).

12. Публічне управління та адміністрування в умовах інформаційного суспільства: вітчизняний і зарубіжний досвід : монографія / за заг. ред. С. Чернова, В. Воронкової, В. Банаха, О. Сосніна, П. Жукаускаса, Й. Ввайнхардт, Р. Андрюкайтене; Запоріз. держ. інж. акад. Запоріжжя : ЗДІА, 2016. $606 \mathrm{c.}$

\section{Information about author:}

Kornuta L. M.,

$\mathrm{PhD}$ in Law, Associate Professor, Associate Professor at the Department of Administrative and Financial Law National University "Odesa Law Academy" 23, Fontanska doroha str., Odesa, 65009, Ukraine 